\title{
Combination of carbohydrases and essential oils improve dietary performance of feedlot steers on a high-energy diet
}

\section{Associação de carboidrases e óleos essenciais melhoram o aproveitamento da dieta em novilhos confinados alimentados com dieta de alta densidade energética}

\author{
Jorge Augusto Dias da Costa Abreu; Mikael Neumann²; Wagner Paris3; André \\ Martins de Souza ${ }^{4 *}$; Gabriela Letícia Delai Vigne5; Eduardo Rodrigues de Almeida6; \\ Fernando Braga Cristo7; Fernando de Souza Sidor ${ }^{8}$
}

\section{Highlights}

Enzymes and essential oils increases the apparent digestibility of starch.

The essential oils stimulated animals to visit the feeder more times a day.

Essential oils caused greater deposition of subcutaneous fat in the rib region.

\begin{abstract}
Essential oils and enzymes are alternatives to feed additives for ruminants that aim to replace the use of ionophores and improve animal performance, but their mechanisms of action are different. Therefore, the present study aimed to verify if there is a synergistic effect in the combined use of enzymes carbohydrates and essential oils on the performance, ingestive behavior and carcass traits of steers fed a high-energy diet. During the finishing period of 78 days, 40 steers were assigned to four treatments: CON- control;

1 M.e in Animal Science, Universidade Tecnológica Federal do Paraná, UTFPR, Dois Vizinhos, PR, Brazil. E-mail: jorge. abreu@safeeds.com.br

2 Prof. Ph.D., Graduate Program in Veterinary Sciences, Department of Veterinary Medicine at the Universidade Estadual do Centro-Oeste, UNICENTRO, Guarapuava, PR, Brazil. E-mail: neumann.mikael@hotmail.com

3 Prof. Ph.D., Graduate Program in Animal Science, Department of Animal Science at the Universidade Tecnológica Federal do Paraná, UTFPR, Dois Vizinhos, PR, Brazil. E-mail: wagner@utfpr.edu.br

${ }^{4}$ Student of the Graduate Program in Animal Science at the Universidade Estadual de Londrina, UEL, Londrina, PR, Brazil. E-mail: andres_92@hotmail.com

${ }^{5}$ Student of the Graduate Program in Animal Science at the UFPR, Curitiba, PR, Brazil. E-mail: gabivigne@hotmail.com

${ }^{6}$ Student of the Graduate Program in Veterinary Sciences at the UNICENTRO, Guarapuava, PR, Brazil. E-mail: eduardo_ tra@hotmail.com

7 M.e. in Veterinary Sciences from the UNICENTRO, Guarapuava, PR, Brazil. E-mail: fernandobragacristo@gmail.com

8 Student of the Graduate Program in Agronomy at the UNICENTRO, Guarapuava, PR, Brazil. E-mail: fernandosiddor@ gmail.com

* Author for correspondence
\end{abstract}

Received: May 28, 2021 - Approved: Nov. 17, 2021 
ENZ- enzymatic complex; EO- essential oil blend; ENZ+EO - enzymatic complex combined with essential oil blend. Regardless of the feedlot periods, the ENZ+EO treatment caused a reduction in the dry matter intake (12.48\%) compared to the control. The ENZ+EO treatment resulted in the lowest mean fecal output and, consequently, the highest dry matter digestibility (DMD) and starch digestibility (SD), compared to the other treatments. Animals that received EO and ENZ+EO in the diet spent more time in feeding. As for the number of times animals visited the feeding trough, the highest values were presented by the animals in the EO, ENZ and ENZ+EO treatments. For the carcass parameters, only the subcutaneous fat thickness on the rib was significantly different between treatments, with the highest values obtained by adding EO and ENZ+EO (8.80 and $8.10 \mathrm{~mm}$ respectively). Thus, the combination of carbohydrate enzymes and essential oils proved to be synergistically beneficial in relation to better use of nutrients and productive performance of feedlot steers.

Key words: Digestibility. Dry matter intake. Enzymes. Feed additive.

\section{Resumo}

Os óleos essenciais e as enzimas são alternativas de aditivos alimentares para ruminantes que visam substituir o uso de ionóforos e melhorar o desempenho animal, porém seus mecanismos de ação são distintos, diante disso, o presente estudo teve por objetivo verificar se há efeito sinérgico no uso associado de enzimas carboidrases e óleos essenciais sobre o desempenho, comportamento ingestivo e características de carcaça de novilhos recebendo dieta de alta densidade energética. Durante 78 dias, período de terminação, 40 novilhos foram distribuídos em quatro tratamentos: CON - controle; ENZ - complexo enzimático; OE - mistura de óleos essenciais; ENZ+OE - complexo enzimático associado a mistura de óleos essenciais. Independentemente dos períodos de confinamento, o tratamento ENZ+OE apresentou maior redução na ingestão de matéria seca $(12,48 \%)$ quando comparado ao controle. $O$ tratamento $\mathrm{ENZ}+\mathrm{OE}$ foi o que apresentou a menor produção média de fezes e a maior digestibilidade da matéria seca (DMS) e digestibilidade do amido (DA), comparado aos demais tratamentos. Os animais que receberam dieta contendo $\mathrm{OE}$ e ENZ+OE passaram maior tempo se alimentando, já em relação ao número de vezes que os animais visitaram o cocho de alimentação, as maiores médias ficaram com os animais dos tratamentos OE, ENZ e ENZ+OE. Para os parâmetros avaliados em carcaça apenas a espessura de gordura subcutânea nas costelas apresentou diferença significativa entre os tratamentos, sendo as maiores médias obtidas pela adição de OE e ENZ+OE (8.80 e 8.10 mm, respectivamente). Dessa forma, a associação de enzimas carboidrases e óleos essenciais mostrou-se sinergicamente benéfica em relação ao melhor aproveitamento dos nutrientes e desempenho produtivo de novilhos confinados.

Palavras-chave: Aditivo alimentar. Digestibilidade. Enzimas. Ingestão de matéria seca.

\section{Introduction}

To meet the growing market demand and for greater profitability, ranchers are increasingly seeking to intensify their production systems, improve carcass standards and generate greater income. An alternative that may meet such concerns is the use of diets with high energy density in feedlot, due to improvements in animal performance and carcass traits (Neumann, Leão, Horst, Figueira, \& Ribas, 2015). 
As most diets with high energy density are low in fibers, the use of technologies that improve the efficiency of diet digestion and have the ability to manipulate ruminal fermentation (Amaro, Lucci, Peixoto, \& Castro, 2002) to avoid metabolic disorders is essential.

Ionophores, especially monensin, are often used to increase animal performance in feedlot systems, as they alter the rumen microbiota and, thus, the rumen fermentation pattern (Drong et al., 2016). However, there has been great interest in seeking natural antimicrobials as a potential alternative to conventional ones, especially after the European Union has banned the use of antibiotics as feed additives (Calo, Crandall, O'Bryan, Corliss, \& Ricke, 2015).

Essential oils are volatile substances, derived from plants, used in medicine, and as a feed flavoring and preservatives (Khorshidian, Yousefi, Khanniri, \& Mortazavian, 2018). In animal nutrition, they have been studied as microbiota modulators because they have a high potential for replacing antibiotics (Mullen et al., 2014; Rossi, Soares, Luchese, \& Santurio, 2015). In a study developed by Zhang et al. (2021), lower diet digestibility was reported when animals were supplemented with essential oils. Heker et al. (2018) working with a blend of essential oils did not find effects on the average daily weight gain, however, at slaughter these animals showed greater thickness of subcutaneous fat.

Like essential oils, exogenous enzymes are harmless to human and animal health. Their use in animal nutrition to improve feed digestibility is widespread, especially in poultry and swine diets. For ruminants, the inclusion of exogenous enzymes in high energy density diets has improved diet digestibility and animal performance (Salem, Gado, Colombatto, \& Elghandour, 2013; Morsy et al., 2016).

Studies on exogenous enzymes have much information about the enzyme activities, however in isolation. This shows that it is also interesting to investigate complexes of enzymes with different activities, which can have a synergistic effect, including with other feed additives, since diets for ruminants are composed of several different substrates, where enzymes act specifically. Even in diets with a high starch content, including whole corn, Neumann et al. (2018) proved to be interesting the use of xylanase enzyme complex to increase feed efficiency of feedlot steers, since Brazilian corn has predominantly vitreous endosperm and, therefore, has a high content of non-starch polysaccharides.

Essential oils and enzymes represent an alternative for replacing ionophores and increasing animal performance, however, their mechanisms of action are different. That is, the combination of enzymes and essential oils may become an alternative that enhances the action of these additives and increases animal performance. However, studies on the combination of these compounds for ruminants are still scarce.

Thus, the present study aimed to evaluate the effect of carbohydrases and essential oils administered alone or in combination in order to verify how they behave in relation to animal performance, ingestive behavior and the carcass traits of steers fed a high-energy density diet, roughage free. 


\section{Material and Methods}

The study was conducted according to ethical standards and approved by the Animal Experimentation Ethics Committee CEUA, protocol number 030/2016.

The whole experiment was carried out in Guarapuava, state of Paraná, from November to January 2017. The climate in the region is subtropical mesothermal humid (Cfb), with no dry season, with cool summers and moderate winter. Guarapuava is at an altitude of approximately $1,100 \mathrm{~m}$, with an annual average rainfall of $1,944 \mathrm{~mm}$, average annual minimum temperature of $12.7^{\circ} \mathrm{C}$, average annual maximum temperature of $23.5^{\circ} \mathrm{C}$, and a relative humidity of $77.9 \%$.

Forty $1 / 2$ Angus $1 / 2$ Nellore steers, uncastrated males, from the same herd, with an average initial body weight (BW) of $436 \pm$ $5 \mathrm{~kg}$ and average age of $14 \pm 2$ months, were housed in 20 feedlot pens, half-roofed, with an area of $15 \mathrm{~m}^{2}$, with a concrete feeder and a drinking fountain. The distribution of animals in the experimental units was performed based on BW and adjusted to the initial rib eye area (REA) and initial subcutaneous fat thickness in the longissimus dorsi muscle (ISFTL) measured between the $12^{\text {th }}$ and $13^{\text {th }}$ ribs, using a set of equipment consisting of an ecocamera (Aloka ${ }^{\circledR}$ SSD-500 Vet) coupled to a $17 \mathrm{~cm}$ and $3.5 \mathrm{MHz}$ probe.

The experiment was carried out in a randomized block design with four treatments consisting of the combination of the following additives included in the diets: CON-control; enzyme complex (ENZ) - Potenzya ${ }^{\circledR}$, at a dose of $5 \mathrm{~g}$ animal day ${ }^{-1}$; essential oil blend (EO) Ruminatus ${ }^{\circledR}$ blend, at a dose of $8 \mathrm{~g}$ animal day $^{-1}$; and (ENZ+EO) - enzyme complex Potenzya ${ }^{\circledR}$ at a dose of $5 \mathrm{~g}$ animal day ${ }^{-1}$ plus essential oil blend Ruminatus ${ }^{\circledR}$ at a dose of 8 $\mathrm{g}$ animal day ${ }^{-1}$, with five replications, where each pen with two animals represented an experimental unit. Both products are manufactured by Safeeds Animal Nutrition.

The essential oil blend Ruminatus ${ }^{\circledR}$ is composed of Eugenia caryophyllata, eugenol, Zygis timo, thymol $\left(64 \mathrm{~g} \mathrm{~kg}^{-1}\right)$, anacardic acid, castor oil and Vanilla pompona (1.000 $\mathrm{mg} \mathrm{kg}^{-1}$ ).

The enzyme complex Potenzya ${ }^{\circledR}$ obtained from the fermentation of the fungi Aspergillus niger and Trichoderma reesei, was subjected to previous analysis of enzyme activity in an assay with 3,5-dinitrosalicylic acid (DNS) (adapted from Miller, 1959), the product is composed of xylanase (3.117 IU g $\left.{ }^{-1}\right)$, cellulase $\left(2.870 \mathrm{IU} \mathrm{g}^{-1}\right), \beta$-glucanase (2.210 IU $\left.\mathrm{g}^{-1}\right)$, mannanase (372 IU $\left.\mathrm{g}^{-1}\right)$, $\alpha$-galactosidase (11 $\mathrm{IU} \mathrm{g}^{-1}$ ) and amylase (21 $\left(\mathrm{U} \mathrm{g}^{-1}\right)$, in the respective conditions of $\mathrm{pH}$ and temperature: xylanase: $\mathrm{pH} 4.5$ and $40^{\circ} \mathrm{C}$; cellulase: $\mathrm{pH} 4.8$ and $50{ }^{\circ} \mathrm{C}$; $\beta$-glucanase, mannanase and amylase: $\mathrm{pH} 5.0$ and $40^{\circ} \mathrm{C}$; and $\alpha$-galactosidase: $\mathrm{pH} 5.5$ and $37^{\circ} \mathrm{C}$.

The experiment lasted 78 days, with 15 days for adaptation of the animals to the diets and facilities and three evaluation periods of 21 days each. In the first four days of adaptation, a total diet consisting of $500 \mathrm{~g} \mathrm{~kg}^{-1}$ of corn silage and $500 \mathrm{~g} \mathrm{~kg}^{-1}$ concentrate mixture was provided; from the fifth to the ninth day, the animals received $300 \mathrm{~g} \mathrm{~kg}^{-1}$ silage and $700 \mathrm{~g}$ $\mathrm{kg}^{-1}$ concentrate mixture; from the $9^{\text {th }}$ to the $14^{\text {th }}$ day, the animals received only $100 \mathrm{~g} \mathrm{~kg}^{-1}$ silage and $900 \mathrm{~g} \mathrm{~kg}^{-1}$ concentrate mixture and from the $15^{\text {th }}$ day on, the forage supply was interrupted, with only the concentrate mixture available ad libitum in the trough.

The diet consisted of a concentrate mixture composed of $850 \mathrm{~g} \mathrm{~kg}^{-1}$ whole corn 
and $150 \mathrm{~g} \mathrm{~kg}^{-1}$ protein concentrate (Table 1), which was composed of soybean meal (224.0 $\left.\mathrm{g} \mathrm{kg}^{-1}\right)$, wheat bran $\left(262.0 \mathrm{~g} \mathrm{~kg}^{-1}\right)$, malt root $\left(199.0 \mathrm{~g} \mathrm{~kg}^{-1}\right)$, ground corn $\left(100.0 \mathrm{~g} \mathrm{~kg}^{-}\right.$ $\left.{ }^{1}\right)$, calcitic limestone $\left(100.0 \mathrm{~g} \mathrm{~kg}^{-1}\right)$, dicalcium phosphate $\left(5.0 \mathrm{~g} \mathrm{~kg}^{-1}\right)$, urea (56.0 $\mathrm{g} \mathrm{kg}^{-1}$ ), common salt $\left(3.0 \mathrm{~g} \mathrm{~kg}^{-1}\right)$, mineral vitamin premix $\left(40.0 \mathrm{~g} \mathrm{~kg}^{-1}\right)$ and bicarbonate $(11.0 \mathrm{~g}$ $\left.\mathrm{kg}^{-1}\right)$. This formulation meets the requirements for $1.5 \mathrm{~kg}$ average daily weight gain, according to the National Research Council [NRC] (2000). The enzyme complex and/or essential oils were previously weighed according to the manufacturer's recommended dose and, at meal times, were added to the diet, which was supplied as total mixed ration (TMR) to ensure the expected intake of the product. Feed was supplied twice a day (6h00 am and $4 \mathrm{hOO} \mathrm{pm}$ ) and intake was recorded daily, through the difference in weight between the amount offered and leftovers from the previous day. The supply was adjusted daily, aiming at an ad libitum offer, considering leftovers of $7 \%$, based on the dry matter of the diet.

\section{Table 1}

Chemical composition of feed and average values of the experimental diet, on a total dry matter (DM) basis

\begin{tabular}{|cccc|}
\hline Parameter & Grain corn & Protein concentrate & Experimental diet ${ }^{1}$ \\
\hline Dry matter, $\mathrm{g} \mathrm{kg}^{-1}$ & 834.6 & 902.2 & 844.7 \\
\hline Ash, $\mathrm{g} \mathrm{kg}^{-1} \mathrm{DM}$ & 7.7 & 163.1 & 31.0 \\
\hline Crude protein, $\mathrm{g} \mathrm{kg}^{-1} \mathrm{DM}$ & 77.2 & 422.3 & 129.0 \\
\hline Ether extract, $\mathrm{g} \mathrm{kg}^{-1} \mathrm{DM}$ & 24.1 & 27.7 & 24.6 \\
\hline Neutral detergent fiber, $\mathrm{g} \mathrm{kg}^{-1} \mathrm{DM}$ & 157.3 & 222.0 & 167.0 \\
\hline Acid detergent fiber, $\mathrm{g} \mathrm{kg}^{-1} \mathrm{DM}$ & 58.3 & 130.8 & 69.2 \\
\hline Starch, $\mathrm{g} \mathrm{kg}^{-1} \mathrm{DM}$ & 570.1 & 168.1 & 509.9 \\
\hline $\mathrm{Ca}, \mathrm{g} \mathrm{kg}^{-1}$ & 0.3 & 37.7 & 5.9 \\
\hline $\mathrm{P}, \mathrm{g} \mathrm{kg}^{-1}$ & 2.5 & 11.1 & 3.8 \\
\hline
\end{tabular}

${ }^{1}$ Composition of the experimental diet: $850 \mathrm{~g} \mathrm{~kg}^{-1}$ whole grain corn and $150 \mathrm{~g} \mathrm{~kg}^{-1}$ protein-vitamin-mineral mixture (Premix guarantee level per kg concentrate: vit. A: 42000 IU; vit D3: 5400 IU; vit. E: 225 IU; Mg: 3.6 g; Na: 3.6 g; Co: 3.0 mg; Cu: $54.1 \mathrm{mg} ; \mathrm{Zn:} 2106.2 \mathrm{mg})$.

During the feedlot period, samples of corn grain and protein concentrate were taken to determine the chemical composition (Table 1). Samples were dried in a forced ventilation oven at $55^{\circ} \mathrm{C}$ to constant weight, and sequentially ground in a Wiley mill with a 1 $\mathrm{mm}$ sieve. Analysis of dry matter (DM), crude protein (CP), ash and ether extract (EE) were performed according to Association of Official Analytical Chemists [AOAC] (1995). The neutral detergent fiber (NDF) content was obtained according to Van Soest, Robertson and Lewis (1991) with thermostable $\alpha$-amylase, and acid detergent fiber (ADF) content, according to Goering and Van Soest (1970). To determine the content of $\mathrm{P}$ and $\mathrm{Ca}$, analyses were performed according to Tedesco, Gianello, Bissani, Bohnen and Volkweiss (1995). Starch content was determined according to Hendrix (1993), based on the hydrolysis of starch contained 
in the sample, after the extraction of soluble carbohydrates with successive washes with $80 \%$ alcohol, and colorimetric analysis of the reducing sugars (glucose), with subsequent conversion of the result into starch.

Animals were weighed the beginning and at the end of the experiment, as well as at the end of each 21-day period, after a 10-hour fast for solids, to determine the average daily weight gain (ADG). Feed and leftovers were weighed daily to determine the dry matter intake, expressed in $\mathrm{kg}$ animal $^{-1}$ day $^{-1}$ (DMI) or expressed as a percentage of body weight (\% BW day $\left.^{-1}\right)$. To evaluate the feed efficiency, the gross feed efficiency (GFE) was calculated as the ratio of $A D G$ to $D M I$.

At the end of the first and third feedlot period, the total feces produced from each experimental unit was collected for 48 hours, divided into 8 six-hour shifts each. Feces were collected after each time the animal defecated and stored in plastic bags, and at the end of each shift, the total produced was weighed and a $500 \mathrm{~g}$ sample was taken to be dried in a ventilated oven at $55^{\circ} \mathrm{C}$ to constant weight. Based on the DMI and fecal output on a dry matter basis in kg per day (FDM), the apparent dry matter digestibility (DMD) was calculated using the following formula:

$\operatorname{DMD}(\%)=1-\frac{\text { ingested DM }- \text { excreted DM }}{\text { ingested DM }} \times 100$

To estimate the apparent starch digestibility (SD), starch content was analyzed in homogeneous samples of the diet and feces, according to the methodology described by Hendrix (1993). SD was calculated using the formula:

$S D(\%)=1-\frac{\text { ingested starch }- \text { excreted starch }}{\text { ingested starch }} \times 100$
The animal ingestive behavior was analyzed for 48 consecutive hours, at the end of the first and third experimental period. Observations were made by six previously trained observers per shift, in a rotation system every six hours. Observations were taken at regular three-minute intervals. Ingestive behavior was represented by water intake and feed intake activities, expressed in hours and times per day, idle and rumination expressed in hours per day. Events of xylophagy, characterized as the behavior in which the animal tries to consume wood to stimulate salivation in response to a low ruminal $\mathrm{pH}$, were also recorded and expressed in times per day. In the night observations, the environment was maintained with artificial lighting in the same way that occurs during the experiment.

At the beginning and at the end of the experiment, carcass ultrasound images were captured with a ALOKA SSD 500 VET device, as mentioned above. Besides REA and final subcutaneous fat thickness in longissimus dorsi (FSFTL), the rump fat thickness (RFT) was measured in the rump region, the subcutaneous fat thickness on the hindquarter (SFTH) was measured on the outer side of the thigh, the subcutaneous fat thickness in the ribs (SFTR) was measured in the rib region, the subcutaneous fat thickness on the forequarters (SFTF) was measured on the outer side of the scapular region, and marbling was measured between the 12th and 13 th ribs across the longissimus dorsi muscle, but with the probe directed to the vertical position, as recommended by Herring, Miller, Bertrand and Benyshek, (1994). For marbling, scores were assigned by indices ranging from 1 (non-existent) to 5 (excessive) adapted from the system proposed by Müller (1987). Images were interpreted by the Designer Genes 
Technology laboratory using the "BIA/DGT Brasil" software.

At the end of the feedlot, animals were fasted for solids for 10 hours, and weighed before shipment to the slaughterhouse, obtaining the farm weight. Upon arrival at the slaughterhouse, animals were fasted in accordance with the legislation and later slaughter followed the sanitary and animal welfare standards. The average carcass gain during the feedlot period (ACG; $\mathrm{kg}^{-1}$ ) was obtained as following:

$$
\mathrm{ACG}=\mathrm{HCW}-(\mathrm{BWi} \times 0.50)
$$

where $\mathrm{ACG}=$ average carcass gain during the feedlot; HCW = hot carcass weight $(\mathrm{kg})$, which was measured in a digital scale on the slaughterhouse and BWi = initial body weight $(\mathrm{kg})$, of animals with a theoretical carcass dressing of $50 \%$. Based on the period of 70 days of feedlot, the average daily carcass gain (ADCG) was expressed in $\mathrm{kg} \mathrm{day}^{-1}$ and calculated as following:

$$
\mathrm{ADCG}=\frac{\mathrm{ACG}}{\mathrm{FP}}
$$

where ADCG = average daily carcass gain; ACG $=$ average carcass gain $(\mathrm{kg})$ during the feedlot period, and FP = feedlot period (days). The efficiency of transformation of the dry matter intake into carcass (ECC) was also calculated, expressed in kg DM kg carcass ${ }^{-1}$, calculations performed as proposed by Horst et al. (2019).

Data obtained for each variable were tested for normality by the Shapiro-Wilk test (PROC UNIVARIATE) and for homogeneity by the Bartlett test (PROC GLM). Subsequently, the results obtained were tested by analysis of variance, and means were compared by Tukey's test at $5 \%$ significance, using the GLM procedure of Statistical Analysis System Institute [SAS Institute] (1993).
For the animal performance and apparent digestibility, the experimental design was randomized blocks (component $\mathrm{Bk})$, with measures evaluated in three periods (Component $\mathrm{Pj}$ ), where the combination of the following additives was considered: control (CON); enzyme complex (ENZ); Blend of essential oils (EO); and an enzyme complex plus a mixture of Essential Oils (ENZ + EO), associated with three evaluation periods, with five replications (20 sampling units), where each pen with two animals represented an experimental unit. Data obtained were tested by analysis of variance using the GLM procedure of SAS Institute (1993). The following statistical model was used: $Y i j k=\mu+A i+P j+B k+(A * P)$ $\mathrm{ij}+$ Eijk; where: Yijk dependent variables; $\mu=$ overall mean of all observations; $\mathrm{A} i=$ effect of additive "i", where $1=\mathrm{CON}, 2=\mathrm{ENZ}, 3=\mathrm{EO}$ and $4=E N Z+E O ; P j=$ effect of feedlot period "j", where 1 = first period, 2 = second period and $3=$ third period for animal performance variables, and $1=$ first period and $3=$ third period for apparent digestibility and ingestive behavior variables; $\mathrm{Bk}=$ effect of the " $k$ " block, with 1 = first, 2 = second, $3=$ third, 4 = fourth and 5 = fifth; $(S * P)$ ij = effect of the interaction between additive and feedlot period "ij" and Eijk = residual random effect.

In all evaluations carried out on the carcass, the experimental design was also completely randomized blocks, however, as this analysis was carried out in a single moment (slaughter), the experimental period factor was not considered, so the statistical model was: $Y_{i j}=\mu+A i+B j+E i j ;$ where: $Y i j$ dependent variables; $\mu=$ overall mean of all observations; $\mathrm{Ai}=$ effect of additive " $\mathrm{i}$ ", where $1=\mathrm{CON}, 2=\mathrm{ENZ}, 3=\mathrm{EO}$ and $4=\mathrm{ENZ}+\mathrm{EO}$; $\mathrm{BK}=$ effect of the " $\mathrm{k}$ " block, with 1 = first, 2 = second, $3=$ third, $4=$ fourth and $5=$ fifth; Eij $=$ residual random effect. 


\section{Results and Discussion}

ADG, DMI and GFE when evaluated during the experimental periods presented lower values ( $p<0.05)$, in general, in the first period (Table 2). This result can be considered positive, as these values tended to rise with the completion of the finishing phase, that is, the animals did not have a compensatory gain at the beginning of the feedlot period due to some feed restriction at the time of rearing.

Table 2

Animal performance and average daily dry matter intake of steers supplemented with carbohydrases and/or essential oils in a roughage-free diet

\begin{tabular}{|c|c|c|c|c|c|c|c|c|}
\hline \multirow[b]{2}{*}{ Diet } & \multicolumn{3}{|c|}{ Feedlot period' } & \multirow[b]{2}{*}{ Mean } & \multirow[b]{2}{*}{ SEM" } & \multicolumn{3}{|c|}{ P-value III } \\
\hline & $\begin{array}{l}1 \text { st period } \\
1-21 \text { days }\end{array}$ & $\begin{array}{l}\text { 2nd period } \\
22-42 \text { days }\end{array}$ & $\begin{array}{l}\text { 3rd period } \\
43-63 \text { days }\end{array}$ & & & A & $P$ & $A \times P$ \\
\hline \multicolumn{9}{|c|}{ Average daily gain, $\mathrm{kg}$ animal ${ }^{-1}$ day $^{-1}$} \\
\hline CON & 1.186 & 1.433 & 1.462 & 1.360 & 0.055 & 0.4989 & 0.0111 & 0.9688 \\
\hline ENZ & 1.076 & 1.262 & 1.281 & 1.206 & & & & \\
\hline EO & 1.095 & 1.529 & 1.414 & 1.346 & & & & \\
\hline $\mathrm{ENZ}+\mathrm{EO}$ & 0.976 & 1.438 & 1.243 & 1.219 & & & & \\
\hline Mean & $1.083 b$ & $1.415 \mathrm{a}$ & $1.350 \mathrm{a}$ & & & & & \\
\hline \multicolumn{9}{|c|}{ Dry matter intake, $\mathrm{kg}$ animal ${ }^{-1}$ day $^{-1}$} \\
\hline CON & 7.79 & 8.19 & 9.26 & 8.41 & 0.17 & 0.0503 & 0.0066 & 0.9845 \\
\hline ENZ & 7.70 & 7.84 & 8.52 & 8.02 & & & & \\
\hline EO & 7.19 & 7.61 & 8.08 & 7.63 & & & & \\
\hline $\mathrm{ENZ}+\mathrm{EO}$ & 6.96 & 6.99 & 8.12 & 7.36 & & & & \\
\hline Mean & $7.41 \mathrm{~b}$ & $7.66 \mathrm{~b}$ & $8.49 a$ & & & & & \\
\hline \multicolumn{9}{|c|}{ Intake per $100 \mathrm{~kg}$ body weight, $\%$} \\
\hline CON & 1.72 & 1.71 & 1.83 & 1.75 & 0.03 & 0.0704 & 0.5684 & 0.9889 \\
\hline ENZ & 1.75 & 1.69 & 1.74 & 1.73 & & & & \\
\hline EO & 1.63 & 1.64 & 1.63 & 1.63 & & & & \\
\hline $\mathrm{ENZ}+\mathrm{EO}$ & 1.57 & 1.50 & 1.64 & 1.57 & & & & \\
\hline Mean & 1.67 & 1.64 & 1.71 & & & & & \\
\hline \multicolumn{9}{|c|}{ Gross feed efficiency, kg gain $\mathrm{kg} \mathrm{DM}^{-1}$} \\
\hline CON & 0.151 & 0.177 & 0.157 & 0.162 & 0.007 & 0.3745 & 0.0104 & 0.7888 \\
\hline ENZ & 0.140 & 0.161 & 0.149 & 0.150 & & & & \\
\hline EO & 0.152 & 0.202 & 0.174 & 0.176 & & & & \\
\hline $\mathrm{ENZ+EO}$ & 0.144 & 0.216 & 0.152 & 0.171 & & & & \\
\hline Mean & $0.147 b$ & $0.189 a$ & $0.158 a b$ & & & & & \\
\hline
\end{tabular}

' First period: experimental days 1-21; Second period: experimental days 22-42; Third period experimental days 43-63. "SEM: standard error of the mean.

II'A: effect of the inclusion of additives; P: effect of the feedlot period; A $\times$ P: interaction between the inclusion of additives and feedlot period.

Means followed by different uppercase letters, in the same column, are significantly different by Tukey's test at $5 \%$. Means followed by different lowercase letters, in the same row, are significantly different by F-test at $5 \%$. 
Regarding the evaluated treatments, the intake, expressed in both $\mathrm{kg}$ animal ${ }^{-1}$ day $^{-}$ 1 , and expressed as a percentage for gain per $100 \mathrm{~kg}$ of BW, showed no difference ( $p>0.05$ ). However, it is possible to note a reduction in dry matter intake of $12.49 \%, 4.63 \%$ and $9.28 \%$ for animals supplemented with ENZ+EO, ENZ and EO compared to the control treatment (Table 2). The main action of essential oils is to modulate ruminal microbiome, reduce deamination and ammonia production, providing a greater flow of nitrogen to the intestine, in addition to reducing methanogenesis, which generates greater energy use in the diet (Patra, 2011; Jafari et al., 2019). Enzymes supplied exogenously when associated with microorganisms present in the animal digestive tract, assist in the release of sugars and other components of complex carbohydrates (Nogueira et al., 2013). These mechanisms of action may have provided the animals of the ENZ+EO treatment with greater use of nutrients, allowing to feel satiety with less ingested volume. The release of these components can promote an increase in the concentration of propionic acid in the rumen, which can affect animal satiety, because when it enters the cycle of gluconeogenesis, it becomes a precursor of glucose, thus stimulating insulin production, generating a reduction in intake (Gonçalves et al., 2012). These reactions may also justify the lower DMI of the animals in the ENZ+EO treatment.

In general, differences in results presented in the literature regarding animal intake with the use of essential oils and/or exogenous enzymes are related to the action of these products, respectively, dependent on the type of oil used, substrate, volume of enzyme administered and the enzyme-substrate ratio (Patra, 2011; Meale, Beauchemin, Hristov, Chaves, \& Mcallister, 2014).
In line with the present study, Hristov et al. (2013) reported reductions in DMI of animals supplemented with essential oils, but they were dairy cows and the doses used were higher, being 250.0, 500.0 and $750.0 \mathrm{~g}$ animal day ${ }^{-1}$. Heker et al. (2018) working with a blend of essential oils at a dose of $1.5 \mathrm{~g}$ animal day $^{-1}$ did not observe a reduction in DMI. When evaluating animal performance also in the finishing phase, Vigne et al. (2018) found gradual increases in DMI when administering exogenous enzymes, regardless of the dose used $\left(0,2.5,5.0\right.$ and $7.5 \mathrm{~g}$ animal day $\left.^{-1}\right)$. In contrast, Neumann et al. (2018) supplemented animals with an enzyme complex, at the finishing phase, at a dose of $10.0 \mathrm{~g}$ animal day $^{-1}$, but did not observe changes in DMI in relation to the control treatment.

DMD and SD showed differences ( $p$ <0.05) between treatments, but when considering the evaluation periods, this effect was not observed ( $p>0.05$ ), as shown in Table 3. The combined use of enzyme complex and blend of essential oils (ENZ+EO) increased DMD and SD, respectively, by $6.73 \%$ and $2.63 \%$, when compared to CON. Individually, the ENZ and EO treatments did not differ for these parameters, however, when compared to CON, DMD increased by $2.85 \%$ and $3.08 \%$ for ENZ and EO, respectively, and SD increased by $0.12 \%$ and $1.42 \%$, respectively.

EO can improve the development of amylolytic bacteria, which are responsible for the increase of propionic acid in the rumen (Oh, Shitani, Koike, \& Kobayashi, 2017). Enzymes that present xylanases and cellulases in their composition can favor the growth of fibrolytic bacteria, and in addition to increasing the production of acetate in the rumen, they can negatively interfere with the digestibility of the diet (Rojo et al., 2015). Nevertheless, the 
combination of EO based on capsiol, thymol and fibrolytic ENZ (pectinase and cellulase) provided an increase in the proportion of propionic acid in the EO and ENZ+EO treatments, when compared to the control and ENZ treatment (Kholif et al., 2018), trends that indicate that the combination of EO with ENZ does not harm the growth of amylolytic bacteria.

Table 3

Apparent digestibility of dry matter, starch and average fecal output in $\mathrm{kg} \mathrm{day}^{-1}$ of steers supplemented with carbohydrase enzymes and/or essential oils added to a roughage-free diet

\begin{tabular}{|c|c|c|c|c|c|c|c|}
\hline \multirow{2}{*}{ Diet } & \multicolumn{2}{|c|}{ Feedlot period' } & \multirow{2}{*}{ Mean } & \multirow{2}{*}{ SEM" } & \multicolumn{3}{|c|}{ P-value ${ }^{|l|}$} \\
\hline & 1st period & 3 rd period & & & A & $\mathrm{P}$ & $A \times P$ \\
\hline \multicolumn{8}{|c|}{ Apparent digestibility of $\mathrm{DM}, \%$} \\
\hline CON & 77.09 & 78.54 & $77.82 \mathrm{~B}$ & 0.57 & 0.0404 & 0.7359 & 0.9459 \\
\hline ENZ & 80.46 & 79.75 & $80.11 \mathrm{AB}$ & & & & \\
\hline EO & 79.98 & 80.61 & $80.30 \mathrm{AB}$ & & & & \\
\hline $\mathrm{ENZ+EO}$ & 83.25 & 83.63 & $83.44 \mathrm{~A}$ & & & & \\
\hline Mean & 80.20 & 80.63 & & & & & \\
\hline \multicolumn{8}{|c|}{ Apparent digestibility of starch, \% } \\
\hline CON & 89.00 & 89.60 & $89.30 \mathrm{~B}$ & 0.49 & 0.0383 & 0.8458 & 0.8420 \\
\hline ENZ & 89.72 & 89.11 & $89.41 \mathrm{AB}$ & & & & \\
\hline EO & 91.43 & 89.75 & $90.59 \mathrm{AB}$ & & & & \\
\hline $\mathrm{ENZ+EO}$ & 91.31 & 92.13 & $91.72 \mathrm{~A}$ & & & & \\
\hline Mean & 90.36 & 90.15 & & & & & \\
\hline \multicolumn{8}{|c|}{ Fecal output, $\mathrm{kg}$ animal ${ }^{-1}$ day $^{-1}$ on NM } \\
\hline CON & 5.66 & 6.51 & $6.09 \mathrm{~A}$ & 0.19 & 0.0438 & 0.3194 & 0.9155 \\
\hline ENZ & 4.92 & 5.60 & $5.26 \mathrm{AB}$ & & & & \\
\hline EO & 4.82 & 5.06 & $4.94 \mathrm{AB}$ & & & & \\
\hline $\mathrm{ENZ+EO}$ & 4.13 & 4.18 & $4.16 \mathrm{~B}$ & & & & \\
\hline Mean & 4.88 & 5.34 & & & & & \\
\hline \multicolumn{8}{|c|}{ Fecal output, $\mathrm{kg}$ animal-1 $\mathrm{day}^{-1}$ on DM } \\
\hline CON & 1.70 & 1.98 & 1.84 & 0.07 & 0.0519 & 0.2985 & 0.9189 \\
\hline ENZ & 1.53 & 1.76 & 1.65 & & & & \\
\hline EO & 1.47 & 1.58 & 1.53 & & & & \\
\hline $\mathrm{ENZ}+\mathrm{EO}$ & 1.28 & 1.30 & 1.29 & & & & \\
\hline Mean & 1.49 & 1.65 & & & & & \\
\hline
\end{tabular}

I Period 1: experimental days 17, 18 and 19; Period 2: experimental days 60, 61 and 62.

"SEM: standard error of the mean.

III A: effect of the inclusion of additives; $P$ : effect of the feedlot period; $A \times P$ : interaction between the inclusion of additives and feedlot period

Means followed by different uppercase letters, in the same column, are significantly different by Tukey's test at $5 \%$. Means followed by different lowercase letters, in the same row, are significantly different by F-test at $5 \%$. 
The higher mean in the apparent DMD and SD for the ENZ + EO treatment in relation to the isolated use of EO and ENZ and the control, suggests that it is the effect of promoting the development of amylolytic bacteria, as already mentioned by Oh et al. (2017), which generates better use of sugars and other compounds from the breakdown of starch carried out by enzymes, as already mentioned.

In general, fecal output in both natural and dry matter, was lower for the ENZ+EO treatment (Table 3), when compared to the other treatments $\left(4.16\right.$ and $1.29 \mathrm{~kg}$ animal $^{-1}$ day $^{-1}$, respectively). The treatments ENZ and EO did not differ from each other. In relation to the evaluation periods, there was also no difference $(p>0.05)$.

The lower production of feces of animals belonging to the ENZ+EO treatment suggests that it is a result of the lower DMI and higher apparent digestibility of the diet
(Tables 2 and 3, respectively). The positive synergism between $\mathrm{EO}$ and ENZ, in addition to suggesting better use of nutrients in the diet, brought benefits in relation to the amount of waste produced, which can become a problem when produced in large quantities and do not have a suitable destination.

With respect to the ingestive behavior in Table 4, the feeding and water intake activities expressed in hours and times day $^{-1}$, xylophagy, idle and rumination when evaluated at different moments of feedlot, in the overall mean, did not differ $(p>0.05)$ from each other. Water intake in hours and times day $^{-1}$ between treatments (CON, EO, ENZ and ENZ+EO) also did not differ. However, for feeding activity expressed in hours and times day $^{-1}$ and xylophagy, there was difference ( $p$ $<0.05$ ) between the treatments CON, OE, ENZ and $\mathrm{ENZ}+\mathrm{EO}$.

\section{Table 4}

Ingestive behavior of steers supplemented with carbohydrase enzymes and/or essential oils added to a roughage-free diet

\begin{tabular}{|c|c|c|c|c|c|c|c|}
\hline \multirow{2}{*}{ Diet } & \multicolumn{2}{|c|}{ Feedlot period" } & \multirow{2}{*}{ Mean } & \multirow{2}{*}{ SEM" } & \multicolumn{3}{|c|}{ P-value III } \\
\hline & 1st period & 3 rd period & & & A & $P$ & $A \times P$ \\
\hline \multicolumn{8}{|c|}{ Feeding, hours day ${ }^{-1}$} \\
\hline CON & 1.01 & 1.28 & $1.15 \mathrm{C}$ & 0.06 & 0.0001 & 0.3960 & 0.1646 \\
\hline ENZ & 1.63 & 1.48 & $1.56 \mathrm{C}$ & & & & \\
\hline EO & 2.84 & 2.24 & $2.54 \mathrm{~A}$ & & & & \\
\hline $\mathrm{ENZ}+\mathrm{EO}$ & 1.80 & 1.80 & $1.80 \mathrm{~B}$ & & & & \\
\hline Mean & 1.82 & 1.70 & & & & & \\
\hline \multicolumn{8}{|c|}{ Water intake, hours day ${ }^{-1}$} \\
\hline CON & 0.24 & 0.16 & 0.20 & 0.01 & 0.0619 & 0.1072 & 0.6906 \\
\hline ENZ & 0.12 & 0.13 & 0.13 & & & & \\
\hline EO & 0.26 & 0.18 & 0.22 & & & & \\
\hline $\mathrm{ENZ}+\mathrm{EO}$ & 0.16 & 0.12 & 0.14 & & & & \\
\hline Mean & 0.20 & 0.15 & & & & & \\
\hline
\end{tabular}

continue... 
continuation...

\begin{tabular}{|c|c|c|c|c|c|c|c|}
\hline \multicolumn{8}{|c|}{ Feeding, times day ${ }^{-1}$} \\
\hline CON & 8.6 & 16.6 & $12.6 \mathrm{~B}$ & 0.5 & 0.0241 & 0.0724 & 0.1026 \\
\hline ENZ & 12.6 & 14.7 & 13.7 AB & & & & \\
\hline EO & 19.9 & 15.6 & $17.8 \mathrm{~A}$ & & & & \\
\hline $\mathrm{ENZ}+\mathrm{EO}$ & 11.9 & 14.9 & 13.4 AB & & & & \\
\hline Mean & 13.2 & 15.5 & & & & & \\
\hline \multicolumn{8}{|c|}{ Water intake, times day ${ }^{-1}$} \\
\hline CON & 7.6 & 5.9 & 6.8 & 0.3 & 0.6464 & 0.4418 & 0.6288 \\
\hline ENZ & 6.0 & 6.4 & 6.2 & & & & \\
\hline EO & 5.6 & 6.0 & 5.8 & & & & \\
\hline $\mathrm{ENZ+EO}$ & 6.1 & 4.9 & 5.5 & & & & \\
\hline Mean & 6.3 & 5.8 & & & & & \\
\hline \multicolumn{8}{|c|}{ Rumination, hours day ${ }^{-1}$} \\
\hline CON & 0.70 & 0.96 & 0.83 & 0.12 & 0.9305 & 0.0509 & 0.9128 \\
\hline ENZ & 0.58 & 1.20 & 0.89 & & & & \\
\hline EO & 0.53 & 1.42 & 0.98 & & & & \\
\hline $\mathrm{ENZ}+\mathrm{EO}$ & 0.49 & 0.96 & 0.73 & & & & \\
\hline Mean & 0.57 & 1.13 & & & & & \\
\hline \multicolumn{8}{|c|}{ Idle, hours day ${ }^{-1}$} \\
\hline CON & 22.03 & 21.60 & 21.82 & 0.13 & 0.0678 & 0.2501 & 0.5901 \\
\hline ENZ & 21.68 & 21.24 & 21.46 & & & & \\
\hline EO & 20.33 & 20.18 & 20.26 & & & & \\
\hline $\mathrm{ENZ}+\mathrm{EO}$ & 21.56 & 21.18 & 21.37 & & & & \\
\hline Mean & 21.40 & 21.05 & & & & & \\
\hline \multicolumn{8}{|c|}{ Xylophagia, times day ${ }^{-1}$} \\
\hline CON & 8.5 & 9.0 & $8.8 \mathrm{~B}$ & 0.5 & 0.0005 & 0.4724 & 0.7913 \\
\hline ENZ & 10.0 & 7.4 & $8.7 \mathrm{~B}$ & & & & \\
\hline EO & 9.0 & 8.5 & $8.8 \mathrm{~B}$ & & & & \\
\hline $\mathrm{ENZ}+\mathrm{EO}$ & 15.7 & 15.1 & $15.4 \mathrm{~A}$ & & & & \\
\hline Mean & 10.8 & 10.0 & & & & & \\
\hline
\end{tabular}

'Period 1: experimental days 17, 18 and 20; period 2: experimental days 60, 61 and 62.

"SEM: standard error of the mean.

III A: effect of the inclusion of additives; P: effect of the feedlot period; A $\times$ P: interaction between the inclusion of additives and feedlot period.

Means followed by different uppercase letters, in the same column, are significantly different by Tukey's test at $5 \%$.

Means followed by different lowercase letters, in the same row, are significantly different by F-test at $5 \%$. 
Animals in the EO treatment spent more hours in the feeder than the others (2.54 hours day $\left.^{-1}\right)$, followed by the animals in the

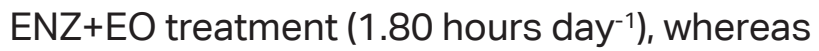
ENZ and CON did not differ from each other. For the feeding activity expressed in times day $^{-1}$, animals of the EO treatment also had a higher mean value (17.8 times day-1), followed by the ENZ+EO and ENZ treatments (13.4 and 13.7 times day ${ }^{-1}$ respectively) and the CON, which visited the feeder less times (12.6 times day $^{-1}$ ).

When analyzing the feed intake of animals in different treatments (Table 4) with weight gain (Table 2), it is noted that one did not interfere with the other, and probably the fluctuations in the number of times that animals went to the feeder and the time they spent feeding are related to physical, chemical and psychogenic factors linked to the diet, which are the main responsible for animal behavior during feeding (Oliveira, Caetano, Caetano, Martins, \& Oliveira, 2017). Among these factors, it is suggested that the one that influenced most the present study was the chemical factor, considering that when the dietary NDF content is not the factor limiting intake, this becomes modulated according to the energy needs of the animal, that is, when the requirements for maintenance and gain are met, intake can be reduced (Oliveira et al., 2017).

For the xylophagy behavior, on average, animals of the ENZ+EO treatment performed this action more times a day than animals in the other treatments, which did not differ from each other. This behavior may be related to an attempt to produce saliva and buffer the rumen $\mathrm{pH}$, because, as already mentioned here, animals in the ENZ+EO treatment may have had a greater production of fatty acids, and according to F. da Silva Vieira, Porto and Gomes (2021), these have a direct relationship with reduced rumen $\mathrm{pH}$. However, this possible drop in ruminal $\mathrm{pH}$ did not harm the health of the animals, as the first sign of metabolic disturbance caused by excessive accumulation of fatty acids in the rumen is a drop in performance (Goularte et al., 2011), a trend not observed in the present study.

Regarding the carcass traits, except for fat thickness on the rib, where the animals of the EO and ENZ+EO treatments showed greater fat thickness compared to animals of the CON or ENZ treatments alone, the other variables did not differ ( $p>0.05$ ) between CON, ENZ, EO, ENZ+EO treatments (Table 5). It is worth mentioning that these parameters have great genetic influences, and as the animals in this study had similar racial and genetic patterns, it may have been a determining factor for the lack of difference between treatments.

Subcutaneous fat has relevant importance in the carcass cooling process, and at this moment, changes occur in areas where they have connective tissue due to water loss, and these changes promote the concentration of salts, which cause oxidation of myoglobin (Lawrie \& Rubensam, 2005). When carcasses reach a minimum value of subcutaneous fat $(3 \mathrm{~mm})$, like that of the animals in the present study, this oxidation is slow, with no changes in meat quality until commercialization (M. R. Silva, Heitor de Paula, Oliveira, Cervelati, \& Pinheiro, 2011). 
Table 5

Carcass traits of steers supplemented with carbohydrase enzymes and/or essential oils added to a roughage-free diet

\begin{tabular}{|c|c|c|c|c|c|c|c|}
\hline \multirow{2}{*}{ Parameters } & \multicolumn{4}{|c|}{ Experimental diet } & \multirow{2}{*}{ Mean } & \multirow{2}{*}{ SEM" } & \multirow{2}{*}{ P-value III } \\
\hline & CON & ENZ & EO & ENZ+EO & & & \\
\hline CY, \% & 54.6 & 54.6 & 55.0 & 54.6 & 54.7 & 0.2 & 0.7019 \\
\hline FREA, $\mathrm{cm}^{2}$ & 84.08 & 83.57 & 86.04 & 81.71 & 83.85 & 0.79 & 0.6065 \\
\hline RFT, mm & 9.71 & 10.50 & 10.13 & 10.08 & 10.11 & 0.20 & 0.8104 \\
\hline ISFTL, mm & 5.60 & 5.50 & 5.90 & 5.80 & 5.70 & 0.12 & 0.5654 \\
\hline FSFTL, mm & 8.17 & 8.33 & 8.19 & 8.14 & 8.21 & 0.21 & 0.9958 \\
\hline SFTH, mm & 4.10 & 3.40 & 3.30 & 3.40 & 3.55 & 0.17 & 0.6595 \\
\hline SFTR, mm & $6.90 \mathrm{~b}$ & $6.90 \mathrm{~b}$ & $8.80 \mathrm{a}$ & $8.10 \mathrm{a}$ & 7.68 & 0.24 & 0.0565 \\
\hline SFTF, mm & 6.20 & 5.80 & 6.50 & 6.00 & 6.13 & 0.2 & 0.8571 \\
\hline Marbling, scores & 3.52 & 3.51 & 3.24 & 3.33 & 3.40 & 0.02 & 0.2558 \\
\hline $\mathrm{ACG}, \mathrm{kg}^{-1}$ & 73.50 & 68.80 & 74.00 & 68.40 & 71.20 & 1.44 & 0.7090 \\
\hline ADCG, kg day ${ }^{-1}$ & 1.05 & 0.983 & 1.057 & 0.977 & 1.017 & 0.022 & 0.7101 \\
\hline ECC, kg DM kg carcass ${ }^{-1}$ & 8.02 & 8.30 & 7.24 & 7.50 & 7.79 & 0.13 & 0.3677 \\
\hline
\end{tabular}

CY: carcass yield; FREA: final rib eye area; RFT: rump fat thickness; ISFTL: initial subcutaneous fat thickness on longissimus dorsi; FSFTL: final subcutaneous fat thickness on longissimus dorsi; SFTH: subcutaneous fat thickness on the hindquarter; SFTR: subcutaneous fat thickness on the ribs; SFTF: subcutaneous fat thickness on the forequarters; ACG: average carcass gain, expressed in $\mathrm{kg}^{-1}$; ADCG: average daily carcass gain, expressed in kg day-1; ECC: efficiency of transformation of the dry matter (DM) into carcass.

"SEM: standard error of the mean

III P-value: effect of the inclusion of additives

Means followed by different lowercase letters, in the same row, are significantly different by Tukey's test at $5 \%$.

Unlike the results obtained in the present study, Neumann et al. (2018) when fed animals with a similar diet (high content of grain corn) and supplemented with an enzyme complex, concluded that the use of exogenous enzymes improves the carcass traits ( $\mathrm{HCW}$, $\mathrm{REA}$, and marbling) of steers finished in feedlot.

\section{Conclusion}

Supplementation of essential oils combined with exogenous enzymes reduced the dry matter intake, without affecting the animal weight gain, and improved the apparent digestibility of dry matter and starch in the diet when compared to the other treatments (control, enzymes and essential oils used alone). However, further studies are required to better explain the mechanism of action of the combination of essential oils and exogenous enzymes as a feed additive for ruminants.

\section{References}

Amaro, F. R., Lucci, C. S., Peixoto, K. C., Jr., \& Castro, A. L. (2002). Effects of levels and adaptation periods to sodium lasalocid on the rumen fermentation parameters. 
Revista Brasileira de Zootecnia, 31(6), 2299-2306. doi: 10.1590/S1516-35982 002000900019

Association of Official Analytical Chemists (1995). Official methods of analysis (16nd ed.). Washington, D.C.: AOAC.

Calo, J. R., Crandall, P. G., O'Bryan, C. A., Corliss, A., \& Ricke, S. C. (2015). Essential oils as antimicrobials in food systems - a review. Food Control, 54(1), 111-119. doi: 10.1016/j.foodcont.2014.12.040

Drong, C., Meyer, U., Von Soosten, D., Frahm, J., Rehage, J., Breves, G., \& Dänicke, S. (2016). Effect of monensin and essential oils on performance and energy metabolism of transition dairy cows. Journal of Animal Physiology and Animal Nutrition, 100(3), 537-551. doi: 10.1111/jpn.12401

Goering, H. K., \& Van Soest, P. J. (1970). Análise de fibras forrageiras: reagentes de aparelhos, procedimentos e algumas aplicações. Washington: Manual Agrícola, DC.

Gonçalves, M. F., Silva Martins, J. M., Oliveira, M. V., Carvalho, C. C. M., Antunes, M. M., Ferreira, I. C., Olivalves, L. C. (2012). lonóforos na alimentação de bovinos. Veterinária Notícias, 18(2), 131-146.

Goularte, S. R., Ítavo, L. C. V., Santos, G. T., Ítavo, C. C. B. F., Oliveira, L. C. S., Favaro, S. P., Bittar, C. M. M. (2011). Ácidos graxos voláteis no rúmen de vacas alimentadas com diferentes teores de concentrado na dieta. Arquivo Brasileiro de Medicina Veterinária e Zootecnia, 63(6), 1479-1486. doi: 10.1590/S010209352011000600027

Heker, J. C. H., Jr., Neumann, M., Ueno, R. K., Falbo, M. K., Galbeiro, S., Souza, A. M.,
Askel, E. J. (2018). Effect of monensin sodium associative to virginiamycin and I or essential oils on the performance of feedlot finished steers. Semina: Ciências Agrárias 39(1), 261-274. doi: 10.5433/1679-0359.2018v39n1 p26

Hendrix, D. L. (1993). Rapid extraction and analysis of nonstructural carbohydrates in plant tissues. Crop Science, 33(6), 1306-1311. doi: 10.2135/cropsci1993.00 11183X003300060037x

Herring, W. O., Miller, D. C., Bertrand, J. K., \& Benyshek, L. L. (1994). Evaluation of machine, technician and interpreter effects on ultrasonic measures of backfat and longissimus muscle area in beef cattle. Journal of Animal Science, 72(9), 2216-2226. doi: 10.2527/1994.7292216x

Horst, E. H., Mareze, J., Bumbieris, V. H., Jr., Neumann, M., Venancio, B. J., \& Souza, A. M. (2019). Performance, carcass characteristics and ingestive behavior of steers fed with silages of different maize hybrids. Arquivo Brasileiro de Medicina Veterinária e Zootecnia, 71(6), 1977-1984. doi: 10.1590/1678-4162-11057

Hristov, A. N., Lee, C., Cassidy, T., Heyler, K., Tekippe, J. A., Varga, G. A., Brandt, R. C. (2013). Effect of OriganumvulgareL. leaves on rumen fermentation, production, and milk fatty acid composition in lactating dairy cows. Journal of Dairy Science, 96(2), 1189-1202. doi: 10.3168/jds.20125975

Jafari, S., Ebrahimi, M., Goh, Y. M., Rajion, M. A., Jahromi, M. F., \& Al-Jumaili, W. S. (2019). Manipulation of rumen fermentation and methane gas production by plant secondary metabolites (saponin, tannin and essential oil): a review of ten-year 
studies. Annals of Animal Science, 19(1), 3-29. doi: 10.2478/aoas-2018-0037

Kholif, A. E., Kassab, A. Y., Azzaz, H. H., Matloup, O. H., Hamdon, H. A., Olafadehan, O. A., \& Morsy, T. A. (2018). Essential oils blend with a newly developed enzyme cocktail works synergistically to enhance feed utilization and milk production of Farafra ewes in the subtropics. Small Ruminant Research, 161(161), 43-50. doi: 10.1016/j. smallrumres.2018.02.011

Khorshidian, N., Yousefi, M., Khanniri, E., \& Mortazavian, A. M. (2018). Potential application ofessentialoilsasantimicrobial preservatives in cheese. Innovative Food Science \& Emerging Technologies, 45(62), 62-72. doi: 10.1016/j.ifset.2017.09.020

Lawrie, R. A., \& Rubensam, J. M. (2005). Ciência da carne (6a ed.). Porto Alegre, RS: Artmed.

Meale, S. J., Beauchemin, K. A., Hristov, A. N., Chaves, A. V., \& Mcallister, T. A. (2014). Revisão por convite do conselho: Oportunidades e desafios no uso de enzimas exógenas para melhorar a produção de ruminantes. Journal of Animal Science, 92(2), 427-442.

Morsy, T. A., Kholif, A. E., Kholif, S. M., Kholif, A. M., Sun, X., \& Salem, A. Z. (2016). Effects of two enzyme feed additives on digestion and milk production in lactating Egyptian buffaloes. Annals of Animal Science, 16(1), 209-222. doi: 10.1515/aoas-2015-0039

Mullen, K. A. E., Lee, A. R., Lyman, R. L., Mason, S. E., Washburn, S. P., \& Anderson, K. L. (2014). An in vitro assessment of the antibacterial activity of plant-derived oils. Journal of Dairy Science, 97(9), 55875591. doi: 10.3168/jds.2013-7806
Müller, L. (1987). Normas para avaliação de carcaças e concurso de carcaça de novilhos. Santa Maria: UFSM.

National Research Council (2000). Nutrient requirements of beef cattle (7nd ed. rev.). Washington, DC: The National Academies Press.

Neumann, M., Leão, G. F. M., Horst, E. H., Figueira, D. N., \& Ribas, T. M. B. (2015). Desempenho de novilhos holandeses recriados com dietas $100 \%$ concentrado inteiramente peletizada ou não. Revista Científica de Produção Animal, 17(2), 76-83. doi: 10.15528/2176-4158/rcpa. v17n2p76-83

Neumann, M., Leão, G. F. M., Horst, E. H., Stuani, O. F., Sangali, C. P., \& Castilho, R. (2018). Exogenous enzymes improve performance and carcass traits of feedlot cattle fed high-grain diet. Revista Brasileira de Zootecnia, 47(1), 1-9. doi: 10.1590/rbz4720170308

Nogueira, S. C. P., Bertpáglia, L., Leandro, G. S., Reis, R. A., Jorge, J. A., \& Polizeli, M. L. T. (2013). Estabilidade xilanásica no rúmen e digestibilidade in vitro de volumosos tratados com extrato enzimático de Aspergillus niveus. Revista Brasileira de Higiene e Sanidade Animal, 7(1), 46-60. doi: 10.5935/1981-2965.20130004

Oh, S., Shitani, R., Koike, S., \& Kobayashi, Y. (2017). Ginkgo fruit extract as an additive to modify rumen microbiota and fermentation and to mitigate methane production. Journal of Dairy Science, 100(3), 1923-1934. doi: 10.3168/ jds.2016-11928

Oliveira, B. C., Caetano, G. A. O., Caetano, M. B., Jr., Martins, T. R., \& Oliveira, C. B. (2017). 
Mecanismos reguladores de consumo em bovinos de corte. Revista Eletrônica Nutritime, 14(4), 6066-6075.

Patra, A. K. (2011). Effects of essential oils on rumen fermentation, microbial ecology and ruminant production. Asian Journal of Animal Veterinary Advances, 6(5), 416428. doi: 10.3923/ajava.2011.416. 428

Rojo, R., Kholif, A. E., Salem, A. Z. M., Elghandour, M. M. Y., Odongo, N. E., Montes de Oca, R., Alonso, M. (2015). Influence of cellulase addition to dairy goat diets on digestion and fermentation milk production and fatty acid content. Journal of Agricultural Science, 153(8), 1514-1523. doi: 10.1017/ SO0 21859615000775

Rossi, C. A., Soares, M., Luchese, F. C., \& Santurio, J. M. (2015). Uso de óleos essenciais no controle dos sinais clínicos das diarreias neonatais em leitões nascidos de fêmeas com diferentes ordens de parto. Ciência Animal Brasileira, 16(1), 93-102. doi: 10.1590/1089-6891v16i119669

Salem, A. Z. M., Gado, H. M., Colombatto, D., \& Elghandour, M. M. Y. (2013). Effects of exogenous enzymes on nutrient digestibility, ruminal fermentation and growth performance in beef steers. Livestock Science, 154(3), 69-73. doi: 10.1016/j.livsci.2013.02.014

Silva, M. R., Heitor De Paula, E. J., Oliveira, D. F.P., Cervelati, K. F., \& Pinheiro, M. S. M. (2011). Importância da deposição de gordura em bovinos de corte e sua mensuração através da técnica de ultrassonografia. Pubvet, 5(15), 1-11.
Silva Vieira, F., Porto, M. R., \& Gomes, R. S. (2021). Avaliação do $\mathrm{pH}$ do fluido ruminal de vacas leiteira e relação com produtividade em propriedades do distrito federal e entorno. Brazilian Journal of Animal and Environmental Research, 4(2), 1699-1707. doi: 10.34188/bjaerv4n2-012

Statistical Analysis System Institute (1993). SAS language reference. Version 6. Cary, NC: SAS Institute Inc.

Tedesco, M. J., Gianello, C., Bissani, C. A., Bohnen, H., \& Volkweiss, S. J. (1995). Análises de solo, plantas e outros materiais (vol. 174). Porto Alegre: UFRGS.

Van Soest, P. J., Robertson, J. B., \& Lewis, B. A. (1991). Symposium: carbohydrate methodology, metabolism, and nutritional implications in dairy cattle. Journal of Dairy Science, 74(10), 3583-3597. doi: 10.3168/ jds.S0022-0302(91)78551-2

Vigne, G. L. D., Neumann, M., Santos, L. C., Dochwat, A., Venancio, B. J., Heker, J. C., Jr., \& Souza, A. M. (2018). Doses of enzyme complex in a high-energy diet on performance and carcass traits of feedlot steers. Revista Brasileira de Zootecnia, 47(1), 1-7. doi: 10.1590/rbz4720170317

Zhang, X. M., Smith, M. L., Gruninger, R. J., Kung, L., Vyas, D., McGinn, S. M., Beauchemin, K. A. (2021). Combined effects of 3-nitrooxypropanol and canola oil supplementation on methane emissions, rumen fermentation and biohydrogenation, and total tract digestibility in beef cattle. Journal of Animal Science, 99(4), 81. doi: 10.1093/ jas/skab081 
